\title{
Estimation of Chlorophyll-a in Northern Coastal Bay of Bengal Using Landsat-8 OLI and Sentinel-2 MSI Sensors
}

\section{OPEN ACCESS}

Edited by:

Katrin Schroeder,

Institute of Marine Science, National

Research Council, Italy

Reviewed by:

Thanan Walesza Pequeno Rodrigues, Instituto Federal Do Pará, Brazil

Fernanda Watanabe,

São Paulo State University, Brazil

*Correspondence:

Debadatta Swain

dswain@iitbbs.ac.in

tORCID:

Debadatta Swain

orcid.org/0000-0001-6324-4107

Specialty section:

This article was submitted to

Physical Oceanography,

a section of the journal

Frontiers in Marine Science

Received: 15 May 2019

Accepted: 05 September 2019

Published: 01 October 2019

Citation:

Poddar S, Chacko N and Swain D (2019) Estimation of Chlorophyll-a in Northern Coastal Bay of Bengal Using

Landsat-8 OLI and Sentinel-2 MSI

Sensors. Front. Mar. Sci. 6:598. doi: 10.3389/fmars.2019.00598

\author{
Shukla Poddar ${ }^{1}$, Neethu Chacko ${ }^{2}$ and Debadatta Swain ${ }^{1 * t}$ \\ ${ }^{1}$ School of Earth, Ocean and Climate Sciences, Indian Institute of Technology Bhubaneswar, Bhubaneswar, India, ${ }^{2}$ Regional \\ Remote Sensing Centre-East, National Remote Sensing Centre, Indian Space Research Organization, Kolkata, India
}

Chlorophyll-a can be used as a proxy for phytoplankton and thus is an essential water quality parameter. The presence of phytoplankton in the ocean causes selective absorption of light by chlorophyll-a pigment resulting in change of the ocean color that can be identified by ocean color remote sensing. The accuracy of chlorophyll-a concentration (Chl-a) estimated from remote sensing sensors depends on the bio-optical algorithm used for the retrieval in specific regional waters. In this work, it is attempted to estimate Chl-a from two currently active satellite sensors with relatively good spatial resolutions considering ocean applications. Suitability of two standard bio-optical Ocean Color (OC) Chlorophyll algorithms, OC-2 (2-band) and OC-3 (3-band) in estimating Chl-a for turbid waters of the northern coastal Bay of Bengal is assessed. Validation with in-situ data showed that OC-2 algorithm gives an estimate of Chl-a with a better correlation of 0.795 and least bias of $0.35 \mathrm{mg} / \mathrm{m}^{3}$. Further, inter-comparison of Chl-a retrieved from the two sensors, Landsat-8 OLI and Sentinel-2 MSI was also carried out. The variability of Chl-a during winter, pre-monsoon, and post-monsoon seasons over the study region were inter-compared. It is observed that during pre-monsoon and post-monsoon seasons, Chl-a from MSI is over estimated compared to OLI. This work is a preliminary step toward estimation of Chl-a in the coastal oceans utilizing available better spatially resolved sensors.

Keywords: chlorophyll-a, ocean color, Landsat-8, Sentinel-2, COMAPS, Bay of Bengal

\section{INTRODUCTION}

Ocean color remote sensing involves estimation of the concentration of substances in ocean by measuring variations in spectral quality of the water surface (IOCCG, 2000). Ocean color is determined by the incident light interactions with substances such as suspended sediments, chromophoric or colored dissolved organic matter (CDOM) and Chlorophyll- $a$ concentration $(\mathrm{Chl}-a)$ present in the water. These substances present in the ocean surface waters are quantified by the water leaving radiance measured in the visible portion of the electromagnetic radiation. Specialized Chl- $a$ pigments selectively absorb light indicating the presence of phytoplankton. Freshwater inputs from the riverine flux and precipitation intermixes with the marine water providing most conducive environment for phytoplankton growth (Rakshit et al., 2014). The spatial variability of the phytoplankton distribution indicated by Chl- $a$ ocean color data has aided in the analysis of biological productivity as well as efficient identification of the potential fishing zones. 
Improvement in ocean color remote sensing with availability of better sensor resolutions over the years has resulted in efficient Chl- $a$ retrieval. Two currently active sensors with mediumspatial resolutions, Operational Land Imager (OLI) on board Landsat-8 (Concha and Schott, 2014; Boucher et al., 2018) and Multi Spectral Imager (MSI) on board Sentinel-2 (ESAEuropean Space Agency, 2015, http://www.esa.int/ ESA) has promoted the more precise Chl- $a$ mapping in recent times (Watanabe et al., 2017). However, accuracy of Chl- $a$ mapped from remote sensing sensors is also largely dependent on the bio-optical algorithm used for its retrieval. The optical properties of regional waters in the coastal zones are likely affected by the presence of CDOM and sediments (Chauhan et al., 2002) apart from phytoplankton. Such waters referred as the Case-2 waters (primarily coastal and inland water bodies) are dominated by inorganic particles whose optical properties are significantly influenced by constituents like mineral particles, CDOM, or microbubbles, in addition to phytoplankton; and the reflectance values become high with increasing turbidity (Mobley et al., 2004). The relationship between the concentrations of aquatic constituents and ocean color being non-linear for case- 2 waters, sensors with high signal-to-noise ratios and high dynamic ranges are needed to carry out measurements effectively in these highly-reflective waters. Consequently, requirements for remote sensing of such waters is rather stringent in terms of sensors and complex in terms of retrieval algorithms (IOCCG, 2000). It is therefore essential to determine the most suitable algorithm for accurate Chl- $a$ estimation of these regional case- 2 waters.

Bay of Bengal is a semi-enclosed tropical basin receiving a large freshwater influx of $1.6 \times 10^{12} \mathrm{~m}^{3} \mathrm{yr}^{-1}$ (Subramanian, 1993). Bay of Bengal has huge freshwater input from the rivers like Krishna, Godavari, Mahanadi, Brahmani, Subarnarekha, Hooghly, Ganges, Brahmaputra, Meghna, Irrawaddy, Sittang, and Salween. Sixty-four percent of the river runoff occurring in the Bay is contributed by the Ganga-Brahmaputra-Meghana river system. The confluence of rivers in the northern Bay deposit a lot of nutrients along with the sediments due to which this region experiences the highest productivity in the entire basin. The northern coastal Bay of Bengal comprises the Hooghly Estuary and Ganga-Brahmaputra delta which are known to have one of the largest sediment deposits in the world $\sim 4,705 \times 10^{6} \mathrm{~mol}$ annually (Mukhopadhyay et al., 2006). Maybe, the funnel shaped by Hooghly estuary located at the northern coastal Bay of Bengal is characterized by extensive fluvial marine deposits carried by the Hooghly river and its offshoots. Significant bias in Chl- $a$ values in this region are due to the suspended sediments carried by the rivers flowing into the northern coastal Bay of Bengal increasing the turbidity. Even though, certain earlier studies (Dwivedi, 1993) highlighted high productivity of northern coastal Bay of Bengal, the accuracy of Chl- $a$ has been susceptible to low sensor spatial resolution and environmental conditions like cloud cover. Therefore, an attempt for estimating Chl- $a$ from two currently active mediumspatial resolution satellite sensors, OLI, and MSI is carried out in this study which provide data very near to the coast, necessary for the type of analysis presented (Nechad et al., 2015;
Watanabe et al., 2017). Till the availability of Landsat-8 OLI (30 m spatial resolution) in year 2014 and Sentinel-2 MSI (10 m spatial resolution) in 2016-17 (Concha and Schott, 2016; Vuolo et al., 2016; Watanabe et al., 2017), the best possible spatial resolutions for coastal ocean studies were at least 10 times coarser $[360 \mathrm{~m}$ for Local Area Coverage products of Oceansat-2 of ISRO (Sarangi et al., 2001)] and MERIS, $500 \mathrm{~m}$ for Geostationary Ocean Color Imager (GOCI), MODIS, VIIRS, SeaWiFS, and CZCS (Hooker et al., 1993; Antoine et al., 2005; Lee et al., 2007; BlondeauPatissier et al., 2014; Ngoc et al., 2019). Various historical and current Ocean Color sensors and their specifications as obtained from International Ocean Color Coordinating Group (IOCCG) are provided in Supplementary Table ST-1. The objectives of this work are to (i) estimate Chl- $a$ concentration in the northern coastal Bay of Bengal using two active satellite sensors with good spatial resolutions for ocean applications, and (ii) to assess the variability and inter-compare the performance of the two sensors, OLI and MSI in estimating Chl- $a$ in the dynamic and highly turbid waters of the northern coastal Bay of Bengal.

\section{DATA AND METHODS}

\section{Data}

Operational Land Imager (OLI) onboard Landsat-8, an American Earth observation satellite launched in May 2013, has a 16 day near coast revisit period. It has nine spectral bands with $30 \mathrm{~m}$ spatial resolution for eight bands and a panchromatic band having a resolution of $15 \mathrm{~m}$. For our analysis, Landsat-8 OLI Level-1 data which are Digital Numbers (DN) are achieved from https://earthexplorer.usgs.gov/ for the years 2013-2017. In Remote Sensing, DN refers to the variable assigned to each pixel of the satellite imagery in the form of a binary integer corresponding to a wavelength band or channel of measurement based on the entire range of energies of the remote sensing system in that channel also reflecting its radiometric resolution. This further implies that the same pixel in the satellite imagery could have multiple values for multiple bands. DN values are used to denote pixels when they have not been calibrated into physically meaningful, quantitative values like radiance or reflectance (or any value derived from them, such as abundance).

Sentinel-2A and 2B are recent European wide-swath, highresolution, multi-spectral imaging missions carrying MSI with 13 spectral channels in the visible/near infrared (VNIR) and short wave infrared spectral range (SWIR), launched in June 2015 and December 2017, respectively. MSI has a spatial resolution of $10 \mathrm{~m}$ and a 5-day revisit period. Both the Sentinel missions provide good quality high resolution data in the form of levels $1 \mathrm{~B}, 1 \mathrm{C}$, and $2 \mathrm{~A}$. Level-1B products are radiometrically corrected imagery in Top Of Atmosphere (TOA) radiance values and in sensor geometry. Level-1C and 2A products are TOA and Bottom-OfAtmosphere Reflectances, respectively, in cartographic geometry. For the inter-comparison of the two sensors, data during the overlapping period in the year 2017 is used. Sentinel-2 MSI cloud free Level-1C data (Top Of Atmosphere Reflectance in cartographic geometry) were used for the inter-comparison of the 
two sensors during the overlapping period of year 2017. Level1C data for Sentinel-2 MSI were obtained from https://scihub. copernicus.eu/.

A cross-validation of the Landsat OLI sensor was further carried out with the Moderate Resolution Imaging Spectroradiometer on the Aqua satellite (MODIS-A). The MODIS instrument on board the Terra and Aqua satellites of USA view the entire Earth's surface every 2 days, acquiring data in 36 spectral bands which are useful for studying the dynamics and processes occurring on land, oceans and the lower atmosphere. For our analysis, MODIS-A Level-1B data sets were used which were obtained from https://ladsweb.modaps.eosdis.nasa.gov/ search/. The Level-1B data sets are calibrated and geolocated radiances at all 36 spectral bands of the MODIS-A instrument.

In situ data collected under Coastal Ocean Monitoring and Prediction System (COMAPS) programme of the Ministry of Earth Sciences (MoES), Govt. of India are used for the validation of the satellite derived chlorophyll. The data collection techniques and norms followed during the data collection programme is described in Coastal Water Quality Measurements Protocol for COMAPS Programme (Kaisary et al., 2012). Under this programme, parameters like sediment concentration, phytoplankton, zooplankton, benthos, etc. are constantly monitored and sampled along the 80 coastal locations in India to ensure the standard of water quality. Data collected for the stations are categorized into zones, shore (for distances till $1 \mathrm{~km}$ from shore or $<5 \mathrm{~m}$ water depth), near shore ( $>1$ to $5 \mathrm{~km}$ or $5-12 \mathrm{~m}$ water depth), and offshore ( $>5 \mathrm{~km}$ or $20-30 \mathrm{~m}$ water depth). Samples are collected for surface, mid-depth and bottom levels.

For Chl- $a$, water samples were collected at 2-3 m depth intervals across the shore. The frequency of the measurements was two times a day corresponding to flood and ebb tides for sites where riverine flow (similar to our study region) is dominant. For beach areas, the sampling was carried out both alongshore and across the shore from High Tide Line and Low Tide Line at minimum $50 \mathrm{~cm}$ depth. Water samples were collected using Niskin bottle samplers along with Temperature, Salinity, and measurement of other physical parameters at fixed stations. About $100-1,000 \mathrm{ml}$ of the water samples were filtered and frozen which were later extracted in the laboratory by grinding and adding acetone, followed by centrifuging the contents and then analyzing the extract using a spectrophotometer followed by obtaining Chl- $a$ using established equations. Certain samplings were done using an in situ radiometer (operating at the water leaving radiance of $490 \mathrm{~nm}$ ) after calibration with Chl-a from water samples at those locations. Further details on in situ Chl$a$ extraction for COMAPS can be found in Kaisary et al. (2012) and Madeswaran et al. (2018).

\section{Methods}

Landsat-8 OLI level-1 data product consists of quantized and calibrated scaled DN values while Level-1 data obtained from Sentinel-2 MSI is the TOA Reflectance. Retrieval of Chl- $a$ from the satellite sensors over the study region involves four steps, (i) Obtaining absolute TOA Reflectance from scaled DN values in case of Landsat-8 OLI and scaled TOA Reflectance for Sentinel-2 MSI, respectively, for all the required bands, (ii) Conversion of TOA Reflectance to Surface Reflectance (actually originating from the water surface), (iii) Conversion of the Surface Reflectance to corresponding Remote Sensing Reflectance $\left(\mathrm{R}_{\mathrm{rs}}\right)$ at these bands, and finally (iv) Retrieval of Chl- $a$ from the $\mathrm{R}_{\mathrm{rs}}$ utilizing Ocean Chlorophyll (OC) algorithms (2band: OC-2, and/or 3-bands: OC-3). The scaled DN values from Landsat-8 OLI and scaled TOA Reflectance from Sentinel-2 MSI for the required bands were converted to corresponding Surface Reflectances using the special-purpose inbuilt calculator in QGIS software. It is noted that the Surface Reflectance mentioned refers to that originating from the water surface.

For Landsat-8 OLI, TOA Reflectance $\left(\rho_{\mathrm{p}}\right)$, which is the unitless ratio of reflected vs. total power energy (NASA, 2011), is calculated using the formulation:

$$
\rho_{\mathrm{p}}=\left(\pi * \mathrm{~L}_{\lambda} * \mathrm{~d}^{2}\right) /\left(\mathrm{ESUN}_{\lambda} * \cos \theta_{\mathrm{s}}\right)
$$

where, $\rho_{\mathrm{p}}$ is the TOA Reflectance, $\mathrm{L}_{\lambda}$ is the spectral radiance at the sensor's aperture (at-satellite radiance), $d$ is the EarthSun distance in astronomical units (provided in Landsat- 8 metadata file available from: https:/earth.esa.int/documents/ 10174/679851/LANDSAT_Products_Description_Document. pdf), $\mathrm{ESUN}_{\lambda}$ is the mean solar exo-atmospheric irradiances, $\theta_{\mathrm{s}}$ is the Solar zenith angle in degrees, which is equal to $\theta_{\mathrm{s}}=$ $90^{\circ}-\theta_{\mathrm{e}}$, where $\theta_{\mathrm{e}}$ is the Sun elevation, and $\pi=3.142$. Sentinel- 2 data which are already scaled TOA Reflectance were converted to absolute TOA Reflectance from the quantification value provided in the metadata.

Surface Reflectance $(\rho)$ are then determined from TOA Reflectance for the two sensors at the necessary bands $(\lambda s)$ following Moran et al. (1992), as:

$$
\rho=\frac{\left[\pi *\left(\mathrm{~L}_{\lambda}-\mathrm{L}_{\mathrm{p}}\right) * \mathrm{~d}^{2}\right]}{\left[T_{v} *\left(\left(\mathrm{ESUN}_{\lambda} * \cos \theta_{s} * T_{z}\right)+\mathrm{E}_{\text {down }}\right)\right]}
$$

where, $L_{p}$ is the path radiance, $T_{v}$ is the atmospheric transmittance in the viewing direction, $\mathrm{T}_{\mathrm{z}}$ is the atmospheric transmittance in the illumination direction, $\mathrm{E}_{\mathrm{down}}$ is the downwelling diffuse irradiance. Following atmospheric correction and Dark Object Subtraction (DOS), $\mathrm{R}_{\mathrm{rs}}$ are obtained from the Land Surface Reflectance following Moses et al. (2015), given by:

$$
R_{r s}(\lambda)=\frac{\rho}{\pi}
$$

The $\mathrm{R}_{\mathrm{rs}}$ obtained for the bands are then used in the bio-optical algorithms for retrieval of Chl- $a$ in ArcGIS software for OLI and MSI sensors. Similarly, Level-1B MODIS-A data is processed in SeaDAS software to obtain Chl- $a$ using OC-2 and OC-3 algorithms through L2gen.

Many different algorithms like OC2 algorithm version-2 (OC2v2), OC3, Global Processing (GPs), Morel-1, 2, 3, and 4 have been developed over the past several years to estimate Chl- $a$ from the reflectance of specific bands obtained from various satellite sensors (O'Reilly et al., 1998, 2000). However, algorithms to estimate Chl- $a$ can be broadly categorized into 
two, empirical algorithms and semi-analytic models. Some of the algorithms require $\mathrm{R}_{\mathrm{rs}}$ values of specific bands obtained from various satellite sensors while others require normalized Water Leaving Radiance $\left(\mathrm{L}_{\mathrm{wn}}\right)$ at specific bands again obtained from various satellite sensors.

Given the dynamic nature of the study region, OC-2 and OC-3 algorithms have formed the obvious choice in our analysis since they are well-suited for case- 2 waters among a number of existing bio-optical algorithms (O'Reilly et al., 2000). These algorithms are based on the non-linear relationship between oceanic reflectance and in situ measured Chl- $a$, more precisely the ratios of reflectance in blue and green bands or their combinations. OC-2 is a modified cubic polynomial algorithm which was originally developed for the SeaWiFS data and tuned to the SeaBAM data (O'Reilly et al., 1998). OC3 algorithm has been used to retrieve low as well as high

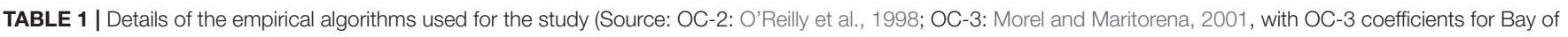
Bengal from Sarangi, 2016).

\begin{tabular}{|c|c|c|}
\hline Algorithm & Equation & Band ratio and coefficients \\
\hline OC-2 & $C=10^{\left(a 0+a 1 \times R+a 2 \times R^{2}+a 3 \times R^{3}\right)}+a 4$ & $\begin{array}{l}R=\log \left(R_{r s} 490 / R_{r s} 555\right) \\
a=0.341,-3.0010,2.811,-2.041,0.0400\end{array}$ \\
\hline OC-3 & $C=10^{\left(a 0+a 1 \times R+a 2 \times R^{2}+a 3 \times R^{3}+a 4 \times R^{4}\right)}$ & $\begin{array}{l}R=\log \left(\left(R_{r s} 443>R_{r s} 488\right) / R_{r s} 555\right)^{\#} \\
a=0.283,-2.753,1.457,-0.659,-1.403\end{array}$ \\
\hline
\end{tabular}

\#(Rrs 443/Rrs 555) or (Rrs 488/Rrs 555), which ever greater is used.

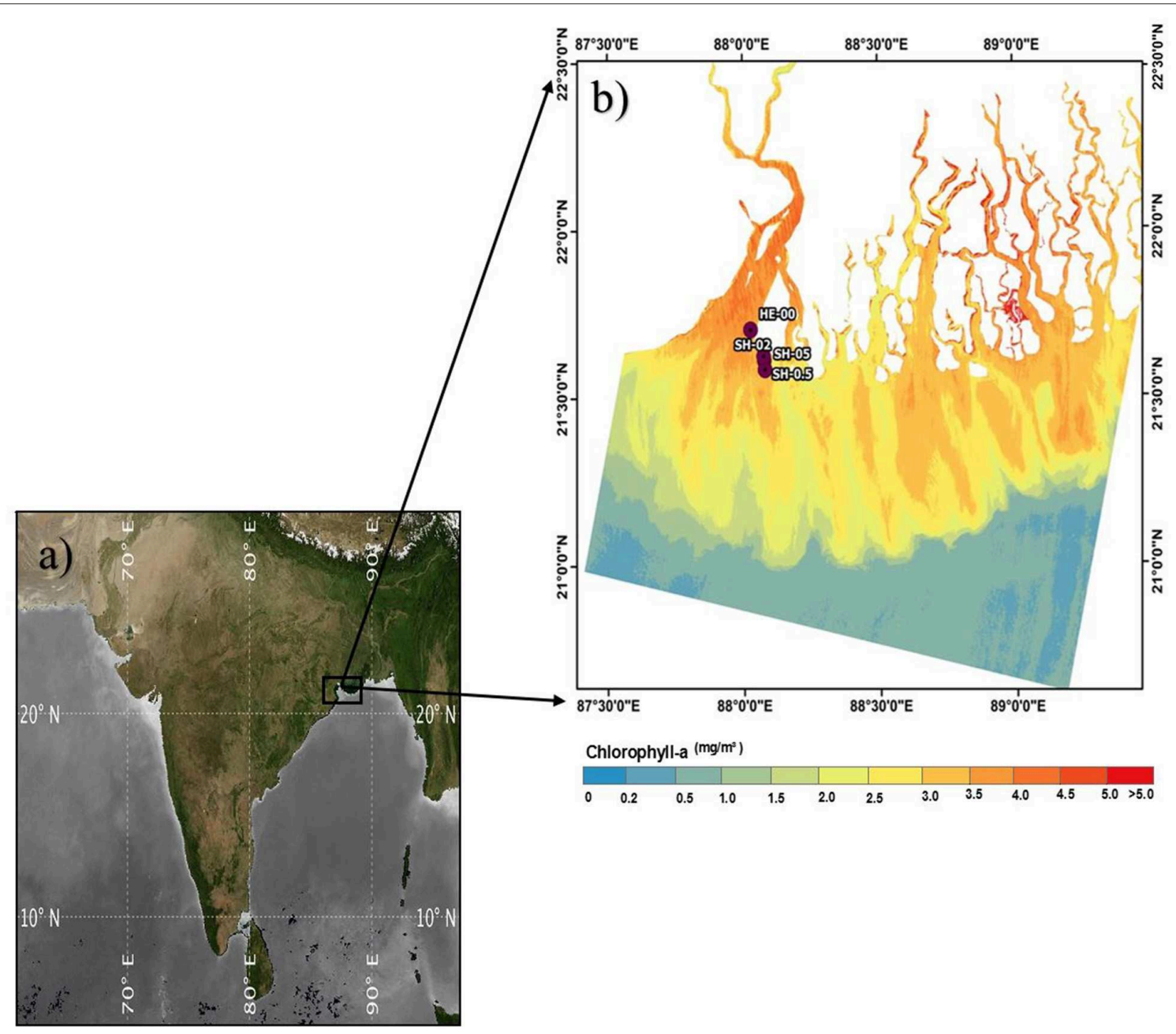

FIGURE 1 | Schematic of the study area: (a) The North Indian Ocean with the domain of interest marked (north coastal Bay of Bengal), (b) Magnified view highlighting the coastal features, locations of the COMAPS data stations, \& pre-monsoon averages (2014-2017) of Chl-a retrieved from Landsat-8 OLI using OC-2 algorithm in the background. 
Chl- $a$ hence making it useful for case- 2 waters like estuarine regions (Morel and Maritorena, 2001). In the present work, OC-2 and OC-3 algorithms were used with the suitable nearest band ratio combination of the two sensors. Table 1 shows the two algorithms used in the present study, their band ratios and coefficients. For OC-2, ratio of $\mathrm{R}_{\mathrm{rs}}$ at 490 and $555 \mathrm{~nm}$ are used. For OC-3, the higher ratio between $\mathrm{R}_{\mathrm{rs}}$ at 443 and 555 or 448 and $555 \mathrm{~nm}$ are used.

Coastal Ocean Monitoring and Prediction System (COMAPS) data used in the present work were available only till the period 2014 for the study area. MSI being a relatively new sensor with data availability only from 2016, the model validation exercise is carried out only for Landsat-8 OLI derived Chl- $a$. Data used for validation are taken from the samples collected at four stations along Hooghly and Sandheads. The study area map comprising of northern coastal Bay of Bengal is shown in Figure 1. Chl- $a$ averages of the pre-monsoon periods during the years $2014-2017$ as retrieved from Landsat-8 OLI using the OC-2 algorithm are overlaid in the background along with the locations of the COMAPS data stations (Figure 1b) The details of the station name, station id, longitude, and latitude are given in Table 2.

For the validation exercise, Landsat-8 OLI data geographically collocated with the corresponding in situ observations during the periods December 2013-March 2014 are extracted and converted to $\mathrm{R}_{\mathrm{rs}}$ to apply OC-2 and OC-3 algorithms and

TABLE 2 | Details of the COMAPS station locations used for validation of Chl-a estimated from Landsat-8 OLI.

\begin{tabular}{lccc}
\hline Station name & Station ID & Latitude $\left({ }^{\circ} \mathbf{N}\right)$ & Longitude $\left({ }^{\circ} \mathbf{E}\right)$ \\
\hline Hooghly Estuary & HE-00 & 21.7047 & 88.0270 \\
Sandheads & $\mathrm{SH}-0.5$ & 21.6257 & 88.0746 \\
Sandheads & $\mathrm{SH}-05$ & 21.5855 & 88.0800 \\
Sandheads & $\mathrm{SH}-02$ & 21.6124 & 88.0771
\end{tabular}

derive Chl- $a$. The statistical metrics used for validation were correlation coefficient $(r)$, Root Mean Square Error (RMSE) and bias. The formula for RMSE and bias are given in Equations (4) and (5).

$$
\begin{array}{r}
R M S E=\sqrt{\frac{\sum_{i=1}^{n}\left(X_{o b s, i}-X_{\text {sensor }, i}\right)^{2}}{n}} \\
\text { bias }=\frac{1}{n} \sum_{i=1}^{n}\left(X_{o b s, i}-X_{\text {sensor }, i}\right)
\end{array}
$$

where, $\mathrm{X}_{\mathrm{obs}, \mathrm{i}}$ is the in-situ data obtained and $\mathrm{X}_{\text {sensor, } \mathrm{i}}$ is the sensor data obtained.

\section{ANALYSIS}

\section{Validation of Satellite Derived Chl-a With COMAPS Data}

Validation of the OC-2 and OC-3 algorithms in the study region were carried out by comparison with COMAPS in situ data sets. In the study region, COMAPS observations are available only till 2014 which were used in our analysis. For validation of Landsat-8 OLI retrieved Chl- $a$ using the OC-2 and OC-3 algorithms, the OLI observations were geographically collocated with corresponding COMAPS in situ observations during the study period in the study region. The metrics of the statistical analysis performed for retrieving Chl- $a$ using OC-2 and OC-3 algorithms are shown in Table 3. " $r$," "bias," and "RMSE" has been computed for OC-2 and OC-3 algorithms. Chl- $a$ retrieved using OC- 2 showed a correlation of 0.795 , while Chl- $a$ retrieved using OC-3 had a slightly lower correlation of 0.786 . A lower bias and RMSE of 0.350 and $0.737 \mathrm{mg} / \mathrm{m}^{3}$, respectively, were obtained using OC-2. Use of OC-3 algorithm resulted in a higher bias and RMSE of 1.063 and $1.237 \mathrm{mg} / \mathrm{m}^{3}$, respectively. Chl- $a$ estimated using both the algorithms are correlating well with the COMAPS data, however a relatively lower bias and RMSE is observed for OC-2 Chl- $a$ estimations. Further, on considering

TABLE 3 | Statistical metrics of validation of Chl-a estimated from Landsat-8 OLI by inter-comparison with in situ (COMAPS) and satellite (MODIS-A) data along with

\begin{tabular}{|c|c|c|c|c|c|}
\hline \multicolumn{2}{|c|}{ Data } & \multicolumn{2}{|c|}{ in situ vs. Landsat-8 OLI } & \multicolumn{2}{|c|}{ MODIS-A vs. Landsat-8 OLI } \\
\hline Parameter & Algorithm & OC-2 & OC-3 & OC-2 & OC-3 \\
\hline Correlation coefficient ( $r$ ) & & 0.795 & 0.786 & 0.750 & 0.713 \\
\hline $\operatorname{Bias}\left(\mathrm{mg} / \mathrm{m}^{3}\right)$ & & 0.360 & 1.063 & 0.967 & 2.487 \\
\hline $\operatorname{RMSE}\left(\mathrm{mg} / \mathrm{m}^{3}\right)$ & & 0.737 & 1.237 & 0.285 & 0.484 \\
\hline \multicolumn{2}{|c|}{ Data } & \multirow{2}{*}{\multicolumn{2}{|c|}{ Standard deviation Chl-a $\left(\mathrm{mg} / \mathrm{m}^{3}\right)$}} & Max. Chl-a $\left(\mathrm{mg} / \mathrm{m}^{3}\right)$ & Min. Chl-a $\left(\mathrm{mg} / \mathrm{m}^{3}\right)$ \\
\hline \multirow[t]{2}{*}{ Algorithm } & Parameter & & & & \\
\hline & in situ & & & 3.348 & 0.529 \\
\hline \multirow[t]{2}{*}{ OC-2 } & MODIS-A & & & 2.614 & 0.259 \\
\hline & Landsat-8 OLI & & & 2.021 & 1.578 \\
\hline \multirow[t]{2}{*}{ OC-3 } & MODIS-A & & & 2.809 & 0.285 \\
\hline & Landsat-8 OLI & & & 2.715 & 2.258 \\
\hline
\end{tabular}
details of in situ Chl-a in the region during this period. 

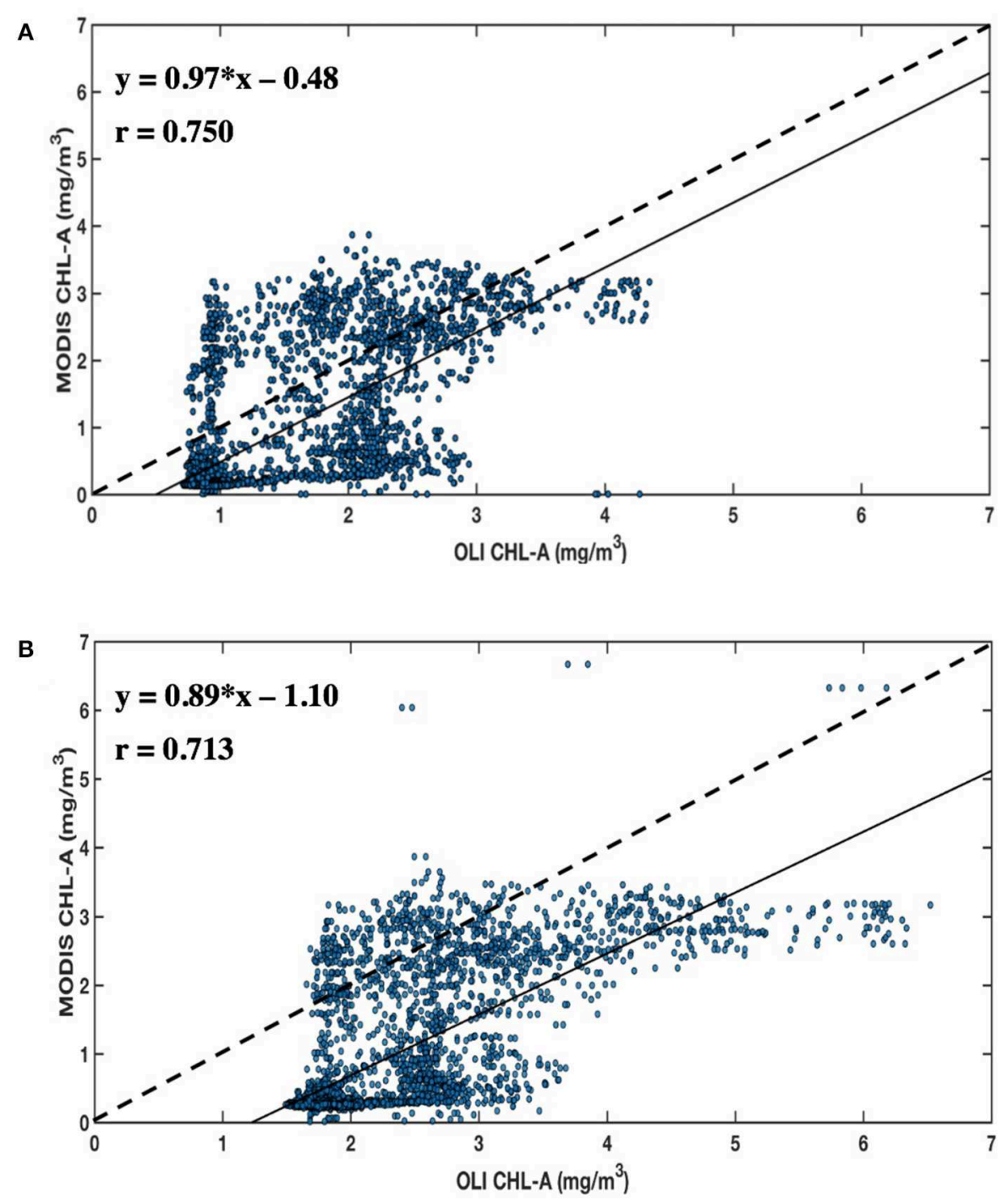

FIGURE 2 | Scatter plots of the Chl-a from MODIS-A vs. Landsat-8 OLI for (A) OC-2 algorithm and (B) OC-3 algorithm, respectively.

the entire study region and not just geographically collocated Chl- $a$, the in situ values (at COMAPS stations) were observed to range between 0.2 and $\sim 8 \mathrm{mg} / \mathrm{m}^{3}$ during post-monsoon to winter periods.

Though our area of interest is the coastal region, a validation exercise was also carried out through inter-comparison of Landsat-8 OLI retrieved Chl- $a$ with MODIS-A derived Chl- $a$ for the region beyond the estuary mouth depending on MODIS data availability. For this, matchups for OLI and MODIS-A during the periods 2013-2014 were obtained for a geographically collocated area chosen within the larger study domain lying between $20^{\circ} 34^{\prime} 38.64^{\prime \prime} \mathrm{N}-21^{\circ} 30^{\prime} 00^{\prime \prime} \mathrm{N}$ and $88^{\circ} 24^{\prime} 50.04^{\prime \prime} \mathrm{E}-$ $91^{\circ} 8^{\prime} 37.68^{\prime \prime} \mathrm{E}$. The scatters between the Chl- $a$ retrievals from MODIS-A and OLI sensors are shown in Figure 2. The satellite sensor inter-comparison revealed a better agreement between Chl- $a$ retrieved from MODIS-A and Landsat- 8 OLI while using the OC-2 algorithm compared to OC-3 algorithm. The correlation between Chl- $a$ from MODIS-A and OLI is 0.750 for OC-2 retrieval algorithm as against a correlation of 0.713 utilizing the OC-3 algorithm. However, Figure 2 also reveals an overestimation of Chl- $a$ by OLI as compared to MODIS$\mathrm{A}$ and with a larger bias for OC-3 than OC-2. It is pertinent to note this does not mean a better retrieval for any or both of these sensors as compared to in situ measurements, but rather an evaluation of the performance of the OC-2 and OC-3 algorithms for Chl- $a$ retrieval from OLI (30 m spatial resolution) vis-à-vis MODIS-A under similar conditions. The metrics of the statistical intercomparison between MODIS-A and Landsat8 OLI are also presented in Table 3. Few details of in situ Chl- $a$ in the study region are also presented in the modified Table to provide a limited but realistic overview of Chl- $a$ variability in the region. Validation of Chl- $a$ derived from Landsat- 8 using 


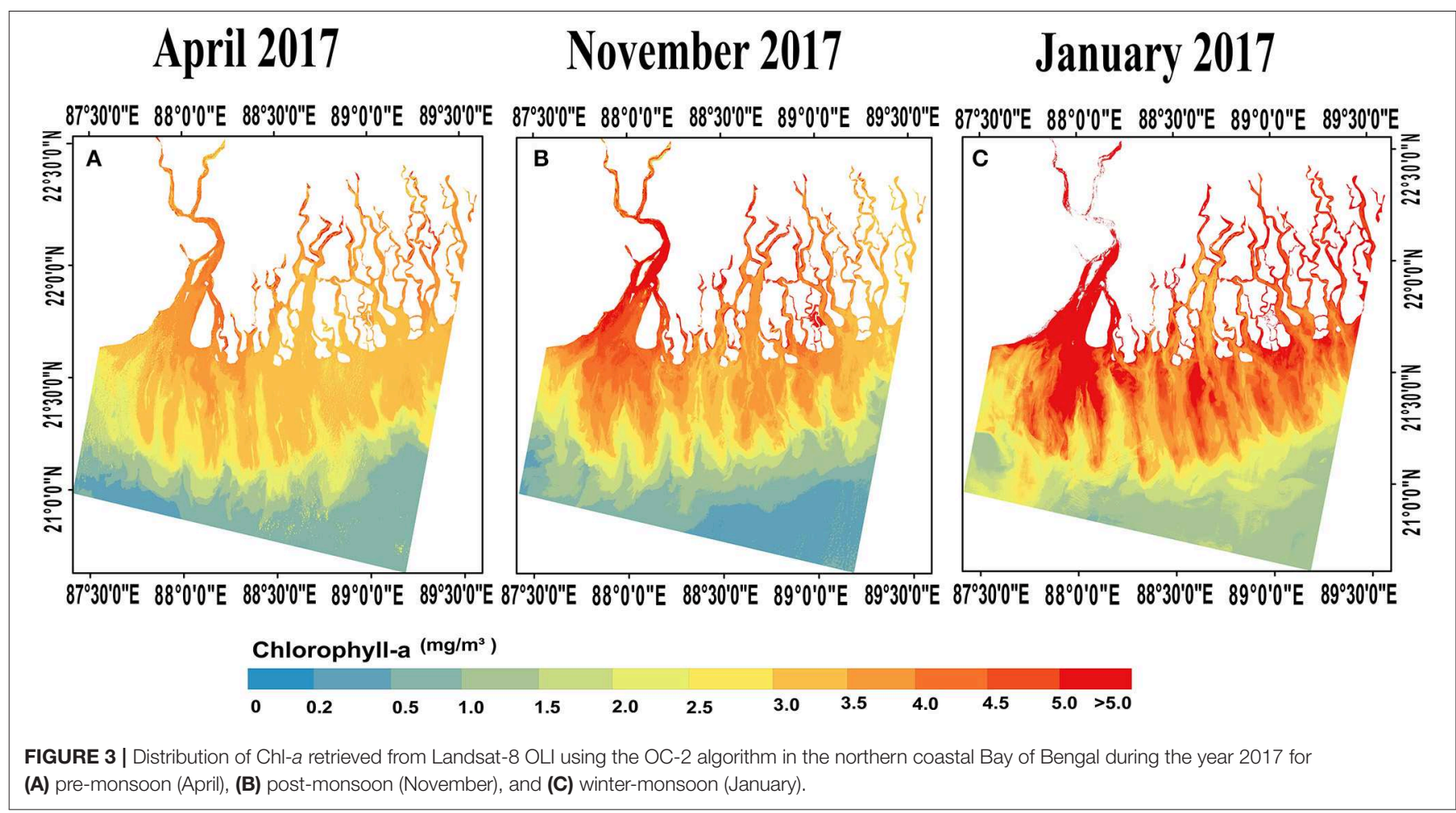

in situ (COMAPS) and satellite (MODIS-A) showed that OC-2 algorithm performs better than OC-3 algorithm. Hence, OC-2 algorithm is used for the estimation of Chl- $a$ and discussed in further sections.

\section{Seasonal Variability of Chl-a Estimated Using Landsat-8 OLI}

Chlorophyll- $a$ concentration (Chl- $a$ ) estimated from Landsat8 OLI using the OC-2 algorithm for the year 2017 is chosen to study its seasonal variability in the coastal Bay of Bengal (Figure 3). It can be noticed that upstream of Hooghly river and the offshoot of the Ganga-Brahmaputra delta record high Chl$a$ values throughout the year with winter season recording the highest $\left(>5 \mathrm{mg} / \mathrm{m}^{3}\right)$ followed by the post-monsoon $\left(4-5 \mathrm{mg} / \mathrm{m}^{3}\right)$ and least during the pre-monsoon $\left(3-4 \mathrm{mg} / \mathrm{m}^{3}\right)$. Similar higher concentration of Chl- $a$ can be found near the mouth of the river openings. Irregular patterns of moderate Chl- $a$ distribution varying between 2.5 and $3.5 \mathrm{mg} / \mathrm{m}^{3}$ (during pre-monsoon and post-monsoon) and reaching upto $4 \mathrm{mg} / \mathrm{m}^{3}$ (during winter season) are observed downstream away from the mouth. Chl- $a$ declines in the offshore $\left(0.5-1 \mathrm{mg} / \mathrm{m}^{3}\right)$.

It can be observed that a periodic increase in the Chl- $a$ is observed with the arrival of each season. Variations in Chl- $a$ is in close relation to the river runoff. The maximum runoff observed during the monsoon and post-monsoon period (JuneOctober) deposits the highest concentration of nutrients which favor the phytoplankton growth and hence enhancement of Chla. The average values of freshwater discharge for Hooghly are $3,000 \mathrm{~m}^{3} / \mathrm{s}$ during the southwest monsoon while $1,000 \mathrm{~m}^{3} / \mathrm{s}$ is discharged during rest of the seasons (Sadhuram et al., 2005).
The northern Bay is primarily fed by the Ganga-BrahmaputraMeghana river system which carries biologically and sediment rich waters during the monsoons. However, winter being a dry season receives very less rainfall over the northern Bay resulting in decreased transport of nutrients by riverine flux for most part near the north of the Bay. However, phytoplankton blooms grow mostly in cooler waters. Despite the presence of nutrients during post-monsoon, enrichment in Chl- $a$ may be found during winter due to the conducive water temperatures along with the presence of pre-deposited nutrients carried by the rivers. The influence of sediments on the optical properties of water is less causing a minimal interference in retrieval of Chl- $a$ during this season. The pre-monsoon season is dry with minimum runoff (both river and agricultural), consequently, a low Chl- $a$ is observed in the region.

\section{Inter-comparison of Chl-a From Sentinel-2 MSI and Landsat-8 OLI}

In this section, Chl- $a$ estimated from the two sensors, Sentinel2 MSI and Landsat-8 OLI are intercompared during their overlapping year 2017. Inter-comparison of the sensors is done on a sub-section of the study area lying in between $20^{\circ} 47^{\prime} 44.062^{\prime \prime} \mathrm{N}-21^{\circ} 40^{\prime} 59.754^{\prime \prime} \mathrm{N}$ and $87^{\circ} 28^{\prime} 36.323^{\prime \prime} \mathrm{E}$ $89^{\circ} 1^{\prime} 13.385^{\prime \prime} \mathrm{E}$ as shown in the Figure 1b which also accommodates the COMAPS in situ observation stations. Chl- $a$ during the three seasons, pre-monsoon, post-monsoon, and winter season is shown in Figure 4. It can be observed that Chl- $a$ values from Sentinel-2 MSI are overestimated compared to those from Landsat-8 OLI during April and November. However, during the winter season (January), Chl- $a$ retrieved from Sentinel-2 MSI are underestimated when compared to Chl- $a$ retrieved from Landsat-8 OLI over the same region. 

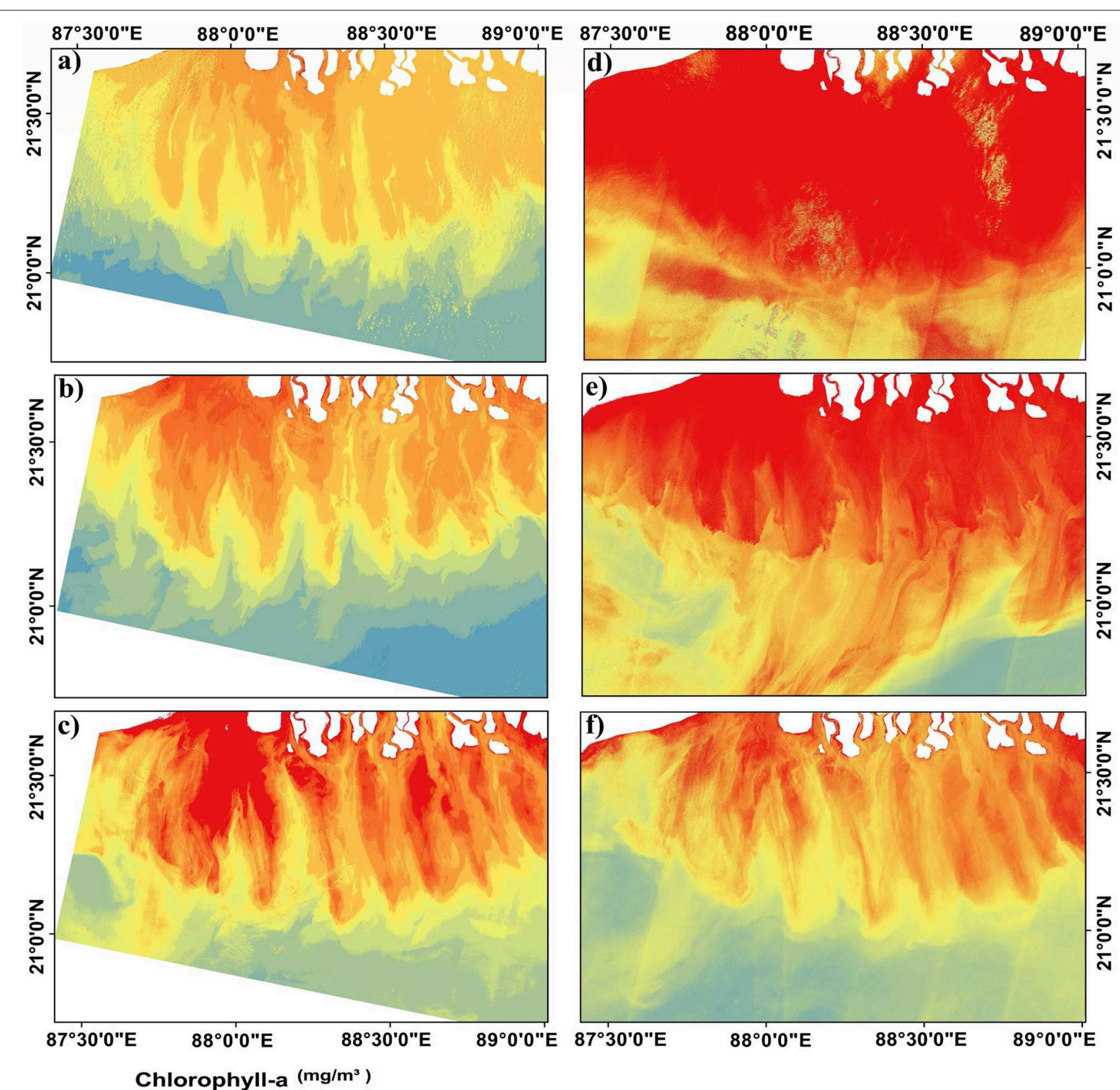

Chlorophyll-a $\left(\mathrm{mg} / \mathrm{m}^{3}\right)$

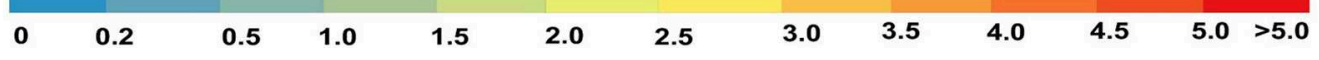

FIGURE 4 | Seasonal distribution of Chl-a during 2017 estimated from (a-c) Landsat-8 OLI, and (d-f) Sentinel-2 MSI.

This difference in retrieved Chl- $a$ values from the two different sensors even though using the same retrieval algorithms could be attributed to the use of same retrieval coefficients for rather two functionally different sensors (MSI vs. OLI).

During the pre-monsoon season the Chl- $a$ traced by OLI exhibits a distinct pattern that is not traced by MSI sensor. The distribution clearly indicates a possible saturation in case of MSI sensor with Chl- $a$ values far $>5 \mathrm{mg} / \mathrm{m}^{3}$ almost in the entire study region. Very close to the Hooghly river mouth, the Chl- $a$ values for OLI sensor lies in the range $3-4 \mathrm{mg} / \mathrm{m}^{3}$ while for MSI sensor Chl- $a$ values $>5 \mathrm{mg} / \mathrm{m}^{3}$ is found covering most of the study area. Irregular patterns of low and high Chl- $a$ are seen upto $21^{\circ} \mathrm{N}$ for both the sensors beyond which values decrease upto 0.5 and 2-3 $\mathrm{mg} / \mathrm{m}^{3}$ for OLI and MSI, respectively. Unlike the pre-monsoon season, the patterns traced by both the sensors is similar. Near the mouth of the estuary the value traced by the OLI sensor lies from 3.5 to $4.5 \mathrm{mg} / \mathrm{m}^{3}$ while extremely high values of Chla ranging $>5 \mathrm{mg} / \mathrm{m}^{3}$ is traced by MSI upto $21^{\circ} 30^{\prime} \mathrm{N}$. Beyond 

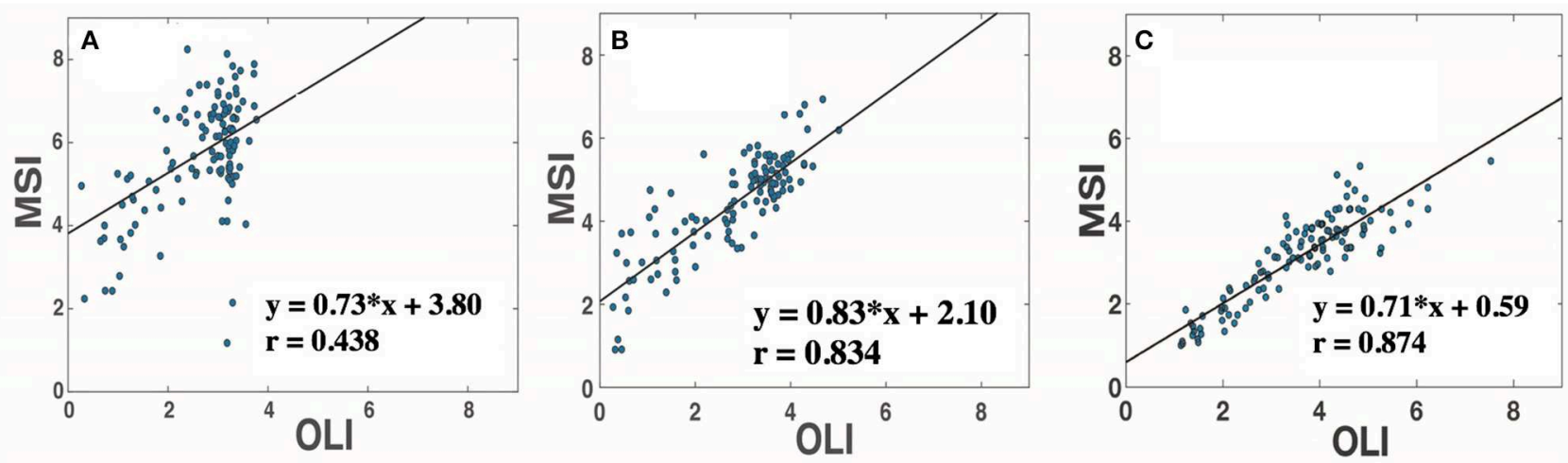

FIGURE 5 | Scatter plots of the Chl-a estimated from Landsat-8 OLI and Sentinel-2 MSI for (A) pre-monsoon (April), (B) post-monsoon (November), and (C) winter-monsoon (January), respectively, during the year 2017.

TABLE 4 | Descriptive statistics of the scatters between Chl-a retrieved from OLI (Landsat-8) and MSI (Sentinel-2) using OC2 algorithm.

Month

OC2-algorithm collocated OLI and MSI observations

\begin{tabular}{|c|c|c|c|c|c|c|}
\hline $\begin{array}{l}\mathrm{SD}_{\mathrm{OLI}} \\
\left(\mathrm{mg} / \mathrm{m}^{3}\right)\end{array}$ & $\mathrm{SD}_{\mathrm{MSI}}\left(\mathrm{mg} / \mathrm{m}^{3}\right)$ & $\begin{array}{l}\text { OLI Chl-a } a_{\max } \\
\left(\text { Chl- } a_{\min }\right)\end{array}$ & $\begin{array}{l}\text { MSI Chl-a } a_{\max } \\
\left(\mathrm{Chl}-a_{\min }\right)\end{array}$ & $\begin{array}{l}\text { OLI vs. MSI } \\
\text { correlation } \\
\text { coefficient }(r)\end{array}$ & $\begin{array}{c}\text { OLI vs. MSI } \\
\text { RMSE } \\
\left(\mathrm{mg} / \mathrm{m}^{3}\right)\end{array}$ & $\begin{array}{c}\text { OLI vs. MSI } \\
\text { Bias } \\
\left(\mathrm{mg} / \mathrm{m}^{3}\right)\end{array}$ \\
\hline
\end{tabular}

\begin{tabular}{|c|c|c|c|c|c|c|c|}
\hline April & 0.884 & 1.287 & $3.972(0.196)$ & $\begin{array}{c}8.238 \\
(1.233)\end{array}$ & 0.438 & 3.368 & 3.095 \\
\hline November & 0.307 & 1.778 & $4.876(0.322)$ & $\begin{array}{c}6.964 \\
(0.933)\end{array}$ & 0.834 & 1.738 & 1.601 \\
\hline January & 1.463 & 1.015 & 7.984 (1.095) & $\begin{array}{c}5.238 \\
(1.020)\end{array}$ & 0.874 & 0.772 & -0.455 \\
\hline
\end{tabular}

The Chl-a minimum values are presented in parentheses in columns 4 and 5.

this, it was observed that Chl- $a$ traced by MSI varies from 2.5 to $3.5 \mathrm{mg} / \mathrm{m}^{3}$ while OLI sensor could record values from 1.0 to 2.5 $\mathrm{mg} / \mathrm{m}^{3}$. During the winter season there is a noticeable shift in the Chl- $a$ traced by both the sensors than the previous months. Very high values of Chl- $a>4 \mathrm{mg} / \mathrm{m}^{3}$ could be traced near the Hooghly estuarine mouth for both the sensors. The values change evolving into distinct patterns near the coast. Chl- $a$ values range from $2.5-4.5$ to $1.5-2.5 \mathrm{mg} / \mathrm{m}^{3}$ near $21^{\circ} \mathrm{N}$, and going to $<1.5 \mathrm{mg} / \mathrm{m}^{3}$ beyond it. Similarity in pattern as well as values for Chl- $a$ traced by OLI sensor could be identified for the MSI sensor. It could be stated that beyond $21^{\circ} \mathrm{N}$ latitude the Chl- $a$ value decreases for both the sensors.

Figure 5 shows the scatters between OLI and MSI for the three different seasons analyzed. Statistical parameters viz. correlation coefficients $(r)$, RMSE and bias were calculated using the formula stated in Equations (4) and (5), respectively, and are given in Table 4. It can be noted that the highest correlation between Chl- $a$ from MSI and OLI is observed for the month of January (winter-monsoon) at 0.874 and the lowest correlation is observed for the month of April (pre-monsoon; 0.438). A strong bias between the Chl- $a$ estimated from the two sensors was observed with the highest being in April $\left(3.095 \mathrm{mg} / \mathrm{m}^{3}\right.$ ) and lowest $\left(-0.455 \mathrm{mg} / \mathrm{m}^{3}\right)$ during the month of January. The highest error $\left(3.368 \mathrm{mg} / \mathrm{m}^{3}\right)$ generated using OC-2 was observed for the April month corresponding to the pre-monsoon season showing appreciable mismatch among the sensors. Post-monsoon season represented by the month of November has a good correlation of 0.833 with a moderate bias and RMSE of 1.601 and $1.738 \mathrm{mg} / \mathrm{m}^{3}$.

\section{CONCLUSIONS}

Northern coastal region is one of the highly productive regions in the Bay of Bengal. Agricultural and river runoff deposit nutrients favorable for phytoplankton growth in this region. Two bio-optical algorithms, OC- 2 and OC- 3 were used to assess the performance of Chl- $a$ estimation from fairly good-spatial resolution sensors Landsat-8 OLI and Sentinel-2 MSI. Results showed that the OC-2 algorithm was able to estimate Chl- $a$ in the northern coastal region reasonably well and was performing better than OC-3 algorithm for OLI. Seasonal variability of Landsat-8 OLI derived Chl- $a$ was analyzed and it was observed that Chl- $a$ increased with the arrival of monsoon season. It was further observed that Chl- $a$ was lowest for the month of April and highest in the month of January (winter season). Seasonality of Chl- $a$ could be closely related to the riverine flux of the GangaBrahmaputra-Meghana river systems. Inter-comparison of Chl- $a$ retrieved from the two sensors (Landsat-8 OLI and Sentinel-2 MSI) was then carried out during their overlapping year 2017. From the analysis, substantial difference was observed in Chl$a$ estimated by both the sensors. Sentinel-2 MSI was found to overestimate Chl-a compared to Landsat-8 OLI, most of the time. 
The present analysis clearly indicated the need for continuous time series in situ observations for Case- 2 waters at several stations. Additionally, sensor inter-comparison and validation exercises for improving the accuracy of Chl- $a$ estimations from satellite based sensors of varying spatial resolutions as well as the need for improved bio-optical algorithms could be wellrecognized for the study region.

\section{DATA AVAILABILITY STATEMENT}

The datasets analyzed for this study can be found in the [USGS (https://earthexplorer.usgs.gov/), scihub (https://scihub. copernicus.eu), Ladsweb (https://ladsweb.modaps.eosdis.nasa. gov/search/), and in-situ COMAPS data is available on request from ICMAM Project Directorate NCCR, MoES, Govt. of India].

\section{AUTHOR CONTRIBUTIONS}

SP was responsible for carrying out the work presented in the manuscript. NC conceived the idea of the work in consultation with DS. DS was responsible for providing useful insights during various stages of the work. All the authors contributed in the discussions of the results and drafting the manuscript.

\section{REFERENCES}

Antoine, D., Morel, A., Gordon, H. R., Banzon, V. F., and Evans, R. H. (2005). Bridging ocean colour observations of the 1980s and 2000s in search of long-term trends. J. Geophys. Res. 110, 1-22. doi: 10.1029/2004JC0 02620

Blondeau-Patissier, D., Gower, J. F. R., Dekker, A. G., Phinn, S. R., and Brando, V. E. (2014). A review of ocean color remote sensing methods and statistical techniques for the detection, mapping and analysis of phytoplankton blooms in coastal and open oceans. Progr. Oceanogr. 123, 123-144. doi: 10.1016/j.pocean.2013.12.008

Boucher, J., Weathers, K. C., Norouzi, H., and Steele, B. (2018). Assessing the effectiveness of Landsat 8 chlorophyll: a retrieval algorithms for regional freshwater monitoring. Ecol. Appl. 28, 1044-1054. doi: 10.1002/eap.1708

Chauhan, P., Mohan, M., Nayak, S. R., and Navalgund, R. R. (2002). Comparison of ocean color chlorophyll algorithms for IRS-P4 OCM sensor using insitu data. J. Indian Soc. Remote Sens. 30, 87-94. doi: 10.1007/BF029 89980

Concha, J. A., and Schott, J. R. (2014). "In-water component retrieval over Case 2 water using Landsat 8: initial results," in 2014 IEEE Geoscience and Remote Sensing Symposium (Québec City, QC).

Concha, J. A., and Schott, J. R. (2016). Retrieval of color producing agents in Case 2 waters using Landsat 8. Remote Sens. Environ. 185, 95-107. doi: 10.1016/j.rse.2016.03.018

Dwivedi, S. N. (1993). "Long-term variability in the food chains, biomass yield, and ocenaography of the Bay of Bengal eco-system," in Large Marine Ecosystems: Stress, Mitigation, and Sustainability, eds K. Sherman, L. M. Alexander, and B. D. Gold (Washington, DC: American Association for the Advancement of Science), 43-52.

ESA-European Space Agency (2015). Sentinel-2A spectral response functions (S2A-SRF): COPE-GSEG-EOPG-TN-15-0007.

Hooker, S. B., McClain, C. R., and Holmes, A. (1993). Ocean colour imaging-CZCS to SeaWiFS. Mar. Technol. Soc. J. 27, 3-15.

IOCCG (2000). "Remote sensing of ocean colour in coastal, and other opticallycomplex, waters," in Reports of the International Ocean-Colour Coordinating Group, No. 3, ed S. Sathyendranath (Dartmouth, NS: IOCCG).

\section{FUNDING}

No specific funding support has been received for carrying out this work. However, one of the authors, SP was supported by MHRD through a GATE fellowship as part of her academic degree programme.

\section{ACKNOWLEDGMENTS}

The authors of this paper would like to thank Indian National Centre for Ocean Information Services (INCOIS) and Integrated Coastal and Marine Area Management (ICMAM) Project Directorate/MoES for providing the data under Coastal Ocean Monitoring and Prediction System (COMAPS) programme for validation purposes. Dr. Ch, Jayaram (RRSC-E, NRSC) is gratefully acknowledged for valuable technical inputs.

\section{SUPPLEMENTARY MATERIAL}

The Supplementary Material for this article can be found online at: https://www.frontiersin.org/articles/10.3389/fmars. 2019.00598/full\#supplementary-material

Kaisary, S., Babu, K. N., Balasubramanian, T., Dileep Kumar, M., Patra, S., Sundaramoorthy, S., et al. (2012). Coastal Water Quality Measurements Protocol for COMAPS Programme. ICMAM Technical report, National Centre For Coastal Research (NCCR), Ministry of Earth Sciences, Govt. of India. 110.

Lee, Z., Carder, K., Arnone, R., and He, M.-X. (2007). Determination of primary spectral bands for remote sensing of aquatic environments. Sensors 7, 3428-3441. doi: 10.3390/s7123428

Madeswaran, P., Ramana Murthy, M. V., Rajeevan, M., Ramanathan, V., Patra, S., Sivasdas, S. K., et al. (2018). Status Report: Seawater Quality at Selected Locations Along Indian Coast. NCCR Publication. 177.

Mobley, C. D., Stramski, D., Bissett, W. P., and Boss, E. (2004). Optical modeling of ocean waters: is the case 1-case 2 classification still useful? Oceanography 17, 60-67. doi: 10.5670/oceanog.2004.48

Moran, M. S., Jackson, R. D., Slater, P. N., and Teillet, P. M. (1992). Evaluation of simplified procedures for retrieval of land surface reflectance factors from satellite sensor output. Remote Sens. Environ. 41, 169-184. doi: 10.1016/0034-4257(92)90076-V

Morel, A., and Maritorena, S. (2001). Bio-optical properties of oceanic waters: a reappraisal. J. Geophys. Res. 106, 7163-7180. doi: 10.1029/2000JC000319

Moses, W. J., Bowles, J. H., and Corson, M. R. (2015). Expected improvements in the quantitative remote sensing of optically complex waters with the use of an optically fast hyperspectral spectrometer-a modeling study. Sensors 15, 6152-6173. doi: 10.3390/s150306152

Mukhopadhyay, S. K., Biswas, H., De, T. K., and Jana, T. K. (2006). Fluxes of nutrients from the tropical River Hooghly at the land-ocean boundary of Sundarbans, NE Coast of Bay of Bengal, India. J. Marine Syst. 62, 9-21. doi: 10.1016/j.jmarsys.2006.03.004

NASA (2011). Landsat 7 Science Data Users Handbook Landsat Project Science Office at NASA's Goddard Space Flight Center in Greenbelt. 186. Available online at: http://landsat.gsfc.nasa.gov/wp-content/uploads/2016/08/Landsat7_ Handbook.pdf (accessed May 5, 2019).

Nechad, B., Ruddick, K., Schroeder, T., Oubelkheir, K., Blondeau-Patissier, D., Cherukuru, N., et al. (2015). CoastColour Round Robin data sets: a database to evaluate the performance of algorithms for the retrieval of water quality parameters in coastal waters. Earth Syst. Sci. Data 7, 319-348. doi: 10.5194/essd-7-319-2015 
Ngoc, D. D., Loisel, H. L., Jamet, C., Vantrepotte, V., Duforêt-Gaurier, L., Minh, C. D., et al. (2019). Coastal and inland water pixels extraction algorithm (WiPE) from spectral shape analysis and HSV transformation applied to Landsat 8 OLI and Sentinel-2 MSI. Remote Sens. Environ. 223, 208-228. doi: 10.1016/j.rse.2019.01.024

O’Reilly, J. E., Maritorena, S., Mitchell, B. G., Siegal, D. A., Carder, K. L., Graver, S. A., et al. (1998). Ocean color chlorophyll algorithms for SeaWiFS. J. Geophys. Res. 103, 24937-24953. doi: 10.1029/98JC02160

O'Reilly, J. E., Maritorena, S., O'Brien, M. C., Siegel, D. A., Toole, D., Menzies, D., et al. (2000). "SeaWiFS post-launch calibration and validation analysis, part 3," in NASA Technical Memorandum-2000-206892, Vol. 11, eds S. B. Hooker and E. R. Firestone (Maryland: NASA Goddard Space Flight Center), 49.

Rakshit, D., Biswas, S. N., Sarkar, S. K., Bhattacharya, B. D., Godhantaraman, N., and Satpathy, K. K. (2014). Seasonal variations in species composition, abundance, biomass and production rate of tintinnids (Ciliata: Protozoa) along the Hooghly (Ganges) River Estuary, India: a multivariate approach. Environ. Monit. Assess. 186, 3063-3078. doi: 10.1007/s10661-0133601-9

Sadhuram, Y., Sarma, V. V., Ramana Murthy, T. V., and Prabhakara Rao, P. B. (2005). Seasonal variability of physico-chemical characteristics of the Haldia channel of Hooghly Estuary, India. J. Earth Syst. Sci. 114, 37-49. doi: $10.1007 / \mathrm{BF} 02702007$

Sarangi, R. K. (2016). Remote sensing observations of ocean surface chlorophyll and temperature with the impact of cyclones and depressions over the Bay of Bengal water. Mar. Geodesy. 39, 53-76. doi: 10.1080/01490419.2015.1121172
Sarangi, R. K., Chauhan, P., Mohan, M., Nayak, S. R., and Navalgund, R. R. (2001). Phytoplankton distribution in the Arabian Sea using IRS-P4 OCM satellite data. Int. J. Remote Sens. 22, 2863-2866. doi: 10.1080/014311601 19527

Subramanian, V. (1993). Sediment load of Indian Rivers. Curr. Sci. 64, 928-930.

Vuolo, F., Zółtak, M., Pipitone, C., Zappa, L., Wenng, H., Immitzer, M., et al. (2016). Data service platform for sentinel-2 surface reflectance and value-added products: system use and examples. Remote Sens. 8, 1-16. doi: 10.3390/rs8110938

Watanabe, F., Alcantara, E., Rodrigues, T., Rotta, L., Bernardo, N., and Imai, N. (2017). Remote sensing of the chlorophyll- $a$ based on OLI/Landsat-8 and MSI/Sentinel-2A (Barra Bonita reservoir, Brazil). An. Acad. Bras. Ciênc. 90, 1987-2000. doi: 10.1590/0001-3765201720170125

Conflict of Interest: The authors declare that the research was conducted in the absence of any commercial or financial relationships that could be construed as a potential conflict of interest.

Copyright (c) 2019 Poddar, Chacko and Swain. This is an open-access article distributed under the terms of the Creative Commons Attribution License (CC BY). The use, distribution or reproduction in other forums is permitted, provided the original author(s) and the copyright owner(s) are credited and that the original publication in this journal is cited, in accordance with accepted academic practice. No use, distribution or reproduction is permitted which does not comply with these terms. 